\title{
The Trichopterygini (Lepidoptera, Geometridae) of Austral South America: description of new species from Chile
}

\author{
Mario I. Ramos-González', Carlos Zamora-Manzur ${ }^{2,3}$, \\ Dania Saladrigas Menés ${ }^{1,3}$, Luis E. Parra'
}

I Departamento de Zoología, Facultad de Ciencias Naturales y Oceanográficas, Universidad de Concepción, Casilla 160-C, Concepción, Chile 2 Departamento de Ecología, Facultad de Ciencias, Universidad Católica de la Santísima Concepción, Alonso de Rivera 2850, Concepción, Chile 3 Programa de Doctorado en Sistemática y Biodiversidad, Facultad de Ciencias Naturales y Oceanográficas, Universidad de Concepción, Concepción, Chile

Corresponding author: Mario I. Ramos-González (marioramos@udec.cl)

Academic editor: Axel Hausmann | Received 26 October 2018 | Accepted 30 January 2019 | Published 19 March 2019

http://zoobank.org/FA9C48CF-0C86-40E3-9EAA-45842E9316B3

Citation: Ramos-González MI, Zamora-Manzur C, Saladrigas Menés D, Parra LE (2019) The Trichopterygini (Lepidoptera, Geometridae) of Austral South America: description of new species from Chile. ZooKeys 832: 91-111. https://doi.org/10.3897/zookeys.832.30851

\begin{abstract}
Four new species belonging to the genera Hoplosauris Butler, Butleriana Parra, Warrenaria Parra, and Fueguina Parra from south-central Chile are described. The species are H. morenoi Ramos-González \& Parra, sp. n., B. phoenix Ramos-González \& Parra, sp. n., W. onca Ramos-González \& Parra, sp. n., and F. araucana Ramos-González \& Parra, sp. n. The genus Aloba Warren is reassigned to tribe Trichopterygini and $A$. carolinae Ramos-González \& Parra, sp. n. is described. Comparative diagnosis for all new species are provided, and illustrations of genitalia and the wing venation of the males for all new described species are given.
\end{abstract}

\section{Keywords}

Andean region, Aloba, Butleriana, Fueguina, Hoplosauris, Larentiinae, taxonomy, Warrenaria

Copyright Mario I. Ramos-González et al. This is an open access article distributed under the terms of the Creative Commons Attribution License (CC BY 4.0), which permits unrestricted use, distribution, and reproduction in any medium, provided the original author and source are credited. 


\section{Introduction}

Geometridae is the second largest family within Lepidoptera, with approximately 23000 species worldwide (Scoble 1999; Scoble and Hausmann 2007; Van Nieukerken et al. 2011). More than 280 geometrid species are known from Chile, 252 of which are endemic (sensu Parra and Villagrán-Mella 2008). However, Parra (1995) estimated the diversity of Chilean geometrids to be at least 450 species.

Larentiinae is the second largest subfamily within Geometridae (Gaston et al. 1995; Scoble et al. 1995), its members occur in a wide variety of habitats, and is particularly abundant at great altitude in the tropics and in temperate forests (Holloway 1997), like those in south-central Chile (Hausmann and Parra 2009; Zamora-Manzur et al. 2011). Despite their high species-richness in Chile (i.e., around half of known Chilean geometrids are larentiines), there are relatively few studies related to these moths as compared to the Ennominae. So far, most research efforts focused on the revision of the genus Eupithecia Curtis (Vojnits 1985, 1992, 1994; Rindge 1987, 1991) and the tribe Trichopterygini (Parra 1991, 1996; Parra and Santos-Salas 1991, 1992; Parra et al. 2009, 2017).

Phylogenetically, Trichopterygini is a group at the base of Larentiinae, sister to all other larentiines, along with Chesiadini and Dyspteridini (Viidalepp 2011; Sihvonen et al. 2011; Ounap et al. 2016). The characteristics that distinguish Trichopterygini are the reduced size of the anal area of male hindwing to a fold, crevice, vesicle, flap or lobe, and the presence of a sternal pouch that does not occlude the tympanal opening (Dugdale 1980; Parra et al. 2017). In Chile, there are 14 genera and 39 species of trichopterygines. A phylogenetic hypothesis at the genus level was formulated by Parra (1991) and Parra et al. (2017). Despite this, no information regarding the natural history of most species is available and there are several undescribed taxa. The aim of this article is to describe five new species for the Chilean fauna and reassign one genus to Trichopterygini.

\section{Methods}

Specimens from the Museum of Zoology of the Universidad de Concepción, Chile (MZUC-UCCC) and Zoologische Staatssammlung München, Germany (ZSM) were examined, as well specimens from field surveys, which were collected using a UV light trap and net sweeping. Activity period (i.e., flight times) and geographic distribution were obtained from each specimen label. All species were assigned to biogeographic provinces proposed by Morrone (2015).

The Barcode Index Number (BIN) of each species is reported which was obtained from the BOLDSystems v4 database (Ratnasingham and Hebert 2007). BINs represent a species-level taxonomic registry of the animal kingdom based on the analysis of nucleotide variation patterns in the barcode region of the cytochrome $\mathrm{c}$ oxidase I (COI) gene (Ratnasingham and Hebert 2013). Genetic distances (when available) were calculated using the Kimura 2-parameter (K2P) distance model, using the analytical tools provided by BOLDSystems $\mathrm{v} 4$ platform. Intra-specific and inter-specific 
genetic distances were reported as maximum and minimum distances, respectively. This genetic information facilitates the species delimitation and form the basis of future phylogenetic works (Brehm 2015, 2018).

The generic assignment of new taxa is based primarily on male genitalia and hindwing venation, which are important characters for the delimitation of species and genera within Trichopterygini (Parra et al. 2017). Species descriptions were made based on external morphological characteristics and genital armature from males and in some cases females. Wing and genitalia slides were prepared according to Parra (1991). Nomenclature for genitalia and external characteristics follow Klots (1970) and Scoble (1995) respectively.

\section{Taxonomy}

\section{Aloba Warren, 1895}

Aloba Warren 1895: 105.

Type species. Hoplosauris cinereus Bartlett-Calvert, 1893, by original designation.

Diagnosis. Palpi short, slightly tilted up. Male: Hindwing subtriangular, valvae with brush-like setal tuft with accessory undulated individual bristles. Female: ductus bursae half the length of corpus bursae. Posterior third of corpus bursae with longitudinal striation; the remaining two thirds with microspines.

Redescription. Antennae filiform in both sexes, but subapically broadened in males. Thorax and abdomen with brownish scales, varying in color from greyish to yellowish shades. Forewings with wide and dark antemedial and postmedial bands; apical spot subquadrate and discal spot always present. In males, hindwings are reduced, subtriangular and whitish; its apex can be extended or not, and there is no visible modification in anal margin. Wing venation in males: forewing with two accessory cells; hindwing with $S_{c}+R_{1}$ and $R s+M_{1}$ separated, $M_{2}$ is free and $M_{3}$ and $\mathrm{Cu}_{1}$ are pedunculated near the angle of discal cell, which is polygonal and it extends for one third of wing surface. Tibial formula 0-2-4 in both sexes. Abdomen is longer and narrower in males than in females. Male genitalia: ensiform valvae with cucullus projected apically, setal tuft is brush-like with accessory and undulated individual bristles, juxta with sclerotized S-shaped lateral processes. Female genitalia: corpus bursae sub-pyriform with longitudinal striation on the posterior third; the remaining two-thirds with microspines on its surface.

\section{Aloba carolinae Ramos-González \& Parra, sp. n.} http://zoobank.org/7C4B292A-F1BE-4EA7-9572-688B20CE23A3

BIN: BOLD:AAD7992

Figures 1, 2, 9, 10, 17

Diagnosis. This species is distinguished from $A$. cinereus (Bartlett-Calvert) by the following characteristics: saccus-vinculum broader, accessorial bristles in setal tuft apically 
undulated, and corpus bursae with the inner surface of its anterior half completely covered with microspines. Externally, this species stands out for its reduced wingspan and for the feather-like extended hindwing apex in males.

Description. Male (Fig. 1). Head: antennae filiform, subapically broadened; palpi short, subequal to eye diameter and slightly tilted upwards. Thorax: Patagia and tegulae covered by piliform grayish scales. Forewings: background color ashy gray; termen rounded, with piliform ashy scales; basal band blackish brown; antemedial band slender, blackish brown, and surrounded by two stripes of ashy-white scales; medial band blackish brown, with a small and subrounded ashy spot on the costal third, medial band with proximal margin arcuate and distal margin with five undulations. Some specimens, in both sexes, with a blackish spot near half of the band and the subrounded ashy spot on the costal third is absent or located in the anal third; postmedial band slender blackish brown and surrounded with two stripes of ashy-white scales; subterminal band zigzagging of whitish scales; apical spot on the wing apex subquadrate and blackish. This spot connects with subterminal band; terminal band formed by a dashed stripe of short blackish spots; distal spot present and blackish. Hindwings: ashy-white, reduced, one-third the length of forewings, triangular with prolonged apex, anal margin with no visible modification; discal spot not visible. Wing venation in males (Fig. 17): same as the genus. Male genitalia (Fig. 9): valvae ensiform, cucullus apically projected, sclerotized costa, subapical setal tuft brush-like with thick, large and undulated individual accessory bristles; saccus subrounded; juxta with quadrate base and posterior apex indented, with two sclerotized and disjointed S-shaped lateral processes, which extend to the height of the transtilla; socius triangular; transtilla projected in a Y-shaped, with apices equal in length. Aedeagus tubular; cornuti arranged as a longitudinal group in the vesica. Female (Fig. 2). Similar to male, but with filiform antennae slighter and hindwings not reduced, quadrangular and ashy-grey. Female genitalia (Fig. 10): ductus bursae half the length of corpus bursae; corpus bursae membranous, subpyriform, with straight longitudinal striation that does not exceed one-third of corpus bursae; anterior region of corpus bursae with microspines on its entire inner surface; cestum present; posterior apophyses larger than anterior apophyses.

Type material. Holotype: $1 \hat{\sigma}$, pinned, Chile, Concepción, Fundo El Guindo Point 1A, 36 $6^{\circ} 50.18^{\prime}$ S, 73⒈40'W, 20-X-2014, leg. M. Ramos \& C. Rose, "Holotype Aloba carolinae" [red handwritten label] (MZUC-UCCC); allotype: 1 , pinned, with genitalia in microscope slide, Chile, Concepción, Fundo El Guindo Point 1B, 36 $6^{\circ} 0.21^{\prime} S, 73^{\circ} 1.39^{\prime} \mathrm{W}, 26-\mathrm{X}-2014$, leg. M. Ramos \& C. Rose, "FGCR LP 109" [genitalia slide] "Allotype Aloba carolinae" [red handwritten label] (UCCC-MZUC).

Paratypes: 46 males, 5 females. Chile: Curicó: Los Queñes, 3459.65'S,

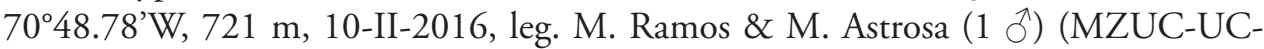
CC); P.N. Radal Siete Tazas, $35^{\circ} 28^{\prime} \mathrm{S}, 71^{\circ} \mathrm{W}, 1100 \mathrm{~m}, 19-\mathrm{XII}-2000$, leg. Gielis [ID BC ZSM Lep 07419, barcode sequence 658 bp; ID BC ZSM Lep 07433, barcode sequence 658 bp] (2 3) (ZSM). Diguillín: Termas de Chillán, 05/11-II-2010, leg. G. Moreno (3 3 ) (MZUC-UCCC); Las Trancas, 01/08-II-2011, leg. G. Moreno (1 §) (MZUC-UCCC); Las Trancas, 03/10-I-2011, leg. G. Moreno (3 §) (MZUCUCCC); Las Trancas, 14/20-I-2012, leg. G. Moreno (1 ठ̂) (MZUC-UCCC); Las 

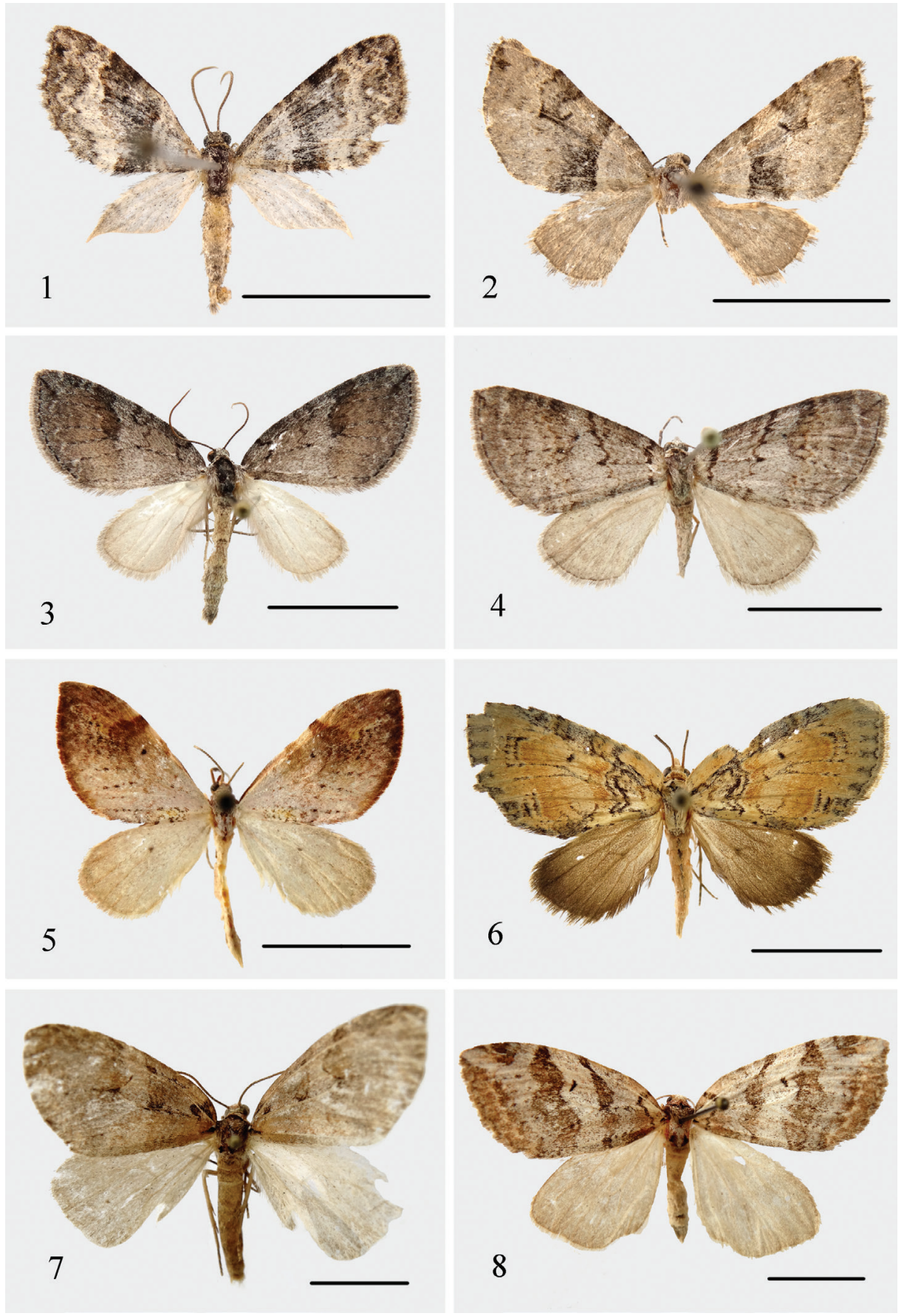

Figures I-8. Adults. I-2 Aloba carolinae Ramos-González \& Parra, sp. n. I male (holotype) $\mathbf{2}$ female (paratype). 3, 4 Hoplosauris morenoi Ramos-González \& Parra, sp. n. 3 male (holotype) 4 female (allotype). 5 Butleriana phoenix Ramos-González \& Parra, sp. n., male (holotype). 6 Warrenaria onca RamosGonzález \& Parra, sp. n., male (holotype). 7, 8 Fueguina araucana Ramos-González \& Parra, sp. n. 7 male (holotype) 8 female (allotype). Scale bar: $1 \mathrm{~cm}$. 


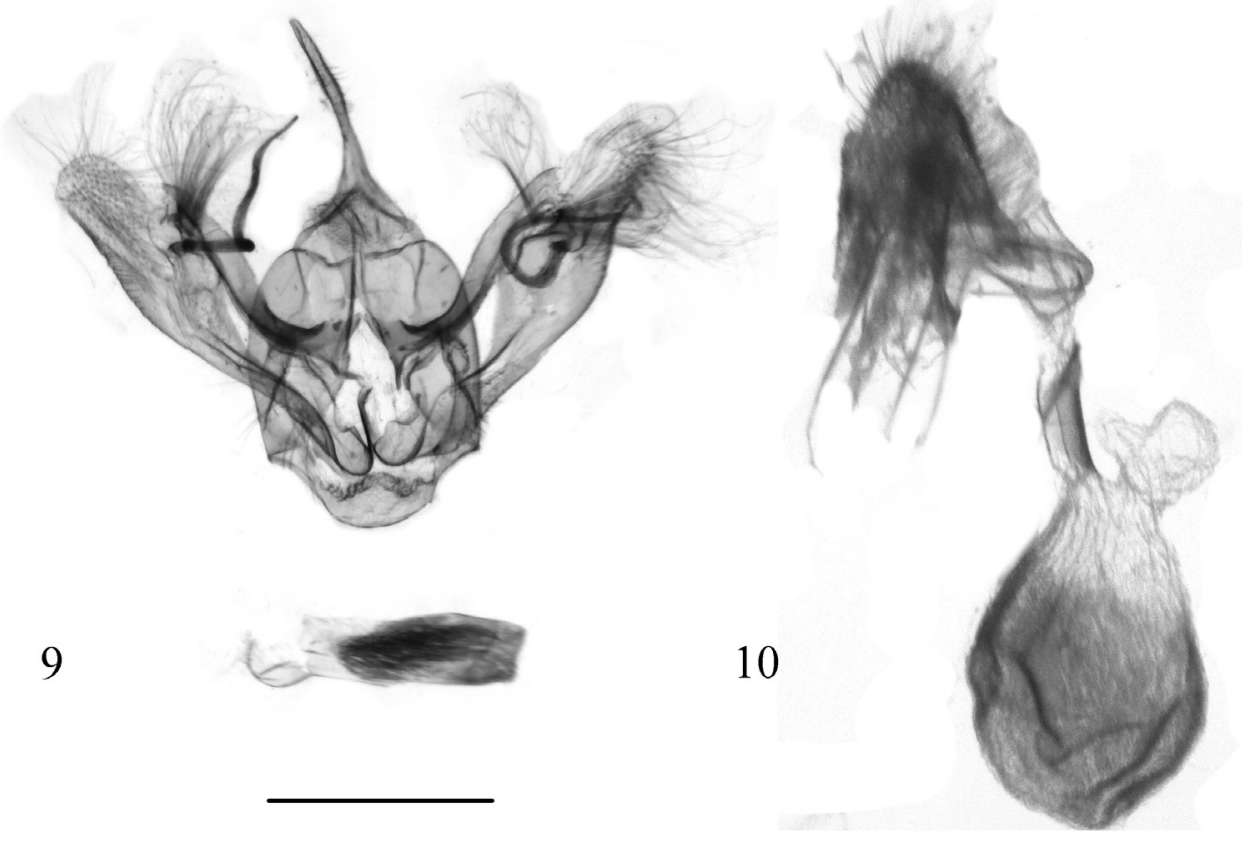

Figures 9, 10. Genitalia of Aloba carolinae Ramos-González \& Parra, sp. n. 9 male genitalia (paratype, MZUC-UCCC, slide No. FGCR LP 103) 10 female genitalia (allotype, MZUC-UCCC, slide no. FGCR LP 109). Scale bar: $1 \mathrm{~mm}$.

Trancas, 16-I-1996, leg. unknown (3 3,1 q) (MZUC-UCCC); Las Trancas, 11-I1996, leg. unknown (1 đ̊) (MZUC-UCCC); Las Trancas, 12-I-2017, leg. P. Bocaz (4 đ); Las Trancas, Cabañas Bordenieve (IX FH), 36 54.83’S, 71²9.69W, 1236 m, 13I-2017, "Hoplo-005" [wing slide], leg. L. Parra, M. Ramos \& C. Zamora-Manzur (1 ふ) (MZUC-UCCC); Las Trancas, 36 $6^{\circ} 4^{\prime}$ S, $71^{\circ} 28^{\prime} \mathrm{W}, 1400 \mathrm{~m}, 14-\mathrm{I}-2001$, leg. Gielis \& Wolf [ID BC ZSM Lep 07435, barcode sequence 658 bp; ID BC ZSM Lep 07431, barcode sequence 658 bp; ID BC ZSM Lep 07417, barcode sequence 658 bp] (2 欠, $^{2}$ 1 †) (ZSM). Concepción: Concepción, 15-XII-1961 (1 ठే) (MZUC-UCCC); same as holotype but "FGCR LP 011", "FGCR LP 012" and "FGCR LP 013" [genitalia slides] (4 ત) (MZUC-UCCC); same as holotype but 26-X-2014, female with "FGCR LP 096" [genitalia slide] (1 $\partial^{7}, 1$ ㅇ) (MZUC-UCCC); same as allotype but "FGCR LP 101" [genitalia slide] ( 1 Љ) (MZUC-UCCC); same as holotype but 03-XI-2014 $\left(4\right.$ ○े $^{\Uparrow}$ (MZUC-UCCC); same as allotype but 03-XI-2014, "FGCR LP 133" [genitalia slide] and "AMLP 103" [wing slide] (1 今) (MZUC-UCCC); same as holotype but Point 1C 36 $30.23^{\prime}$ S, $73^{\circ} 1.39^{\prime} \mathrm{W}, 26-\mathrm{X}-2014$, "FGCR LP 103” [genitalia slide] and "AMLP 0088" [wing slide] (3 $\left.{ }^{\top}\right)$ (MZUC-UCCC); same as holotype but Point 2A 36 30.23 'S, $73^{\circ} 1.47^{\prime} \mathrm{W}, 21-\mathrm{X}-2014$, “FGCR LP 110”, “FGCR LP 132” [genitalia slide] and "AMLP 0102" [wing slide] (3 $\left.{ }^{\AA}\right)$ (MZUC-UCCC); same as holotype but

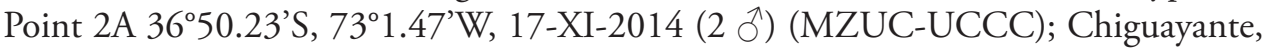


06-III-2002, leg. P. Bocaz (1 q) (MZUC-UCCC). Cautín: $15 \mathrm{~km} \mathrm{NE} \mathrm{from} \mathrm{Colico}$ Lake, 39³'S, 7149.02’W, 400 m, 03-XII-2000, leg. Gielis [ID BC ZSM Lep 03051, barcode sequence 613 bp] (1 $\left.\hat{o}^{\Uparrow}\right)$ (ZSM). Palena: Fiordo Comau, San Ignacio del Huinay, 42²2.82'S, 72²4.8'W, 35 m, 20-II-2008, leg. T. Roy [ID BC ZSM Lep 16933, barcode sequence 658 bp; ID BC ZSM Lep 16922, barcode sequence 658 bp; ID BC ZSM Lep 16936, barcode sequence 658 bp; ID BC ZSM Lep 16923, barcode sequence $658 \mathrm{bp}$ ] (3 $\widehat{\jmath}, 1$ O ) (ZSM).

Distribution. This species occurs between Curicó and Palena provinces. It is distributed in parts of Santiago, Maule and Valdivian Forest biogeographic provinces, Central Chilean and Subantarctic subregions, Andean region.

Flight period. Specimens were captured from October to March.

Molecular data. BOLD:AAD7992. Ten available sequences of DNA barcode: BC ZSM Lep 07419 (Molina), BC ZSM Lep 07433 (Molina), BC ZSM Lep 07431 (Pinto), BC ZSM Lep 07417 (Pinto), BC ZSM Lep 07435 (Pinto), BC ZSM Lep 03051 (Cunco), BC ZSM Lep 16933 (Huinay), BC ZSM Lep 16922 (Huinay), BC ZSM Lep 16936 (Huinay), BC ZSM Lep 16923 (Huinay). Maximum intraspecific distance: 0.76\%; Minimum genetic distance with $A$. cinereus: $9.35 \%$.

Etymology. The species name is dedicated to the collector and biologist Carolina Rose Garrido, Concepción, Chile.

\section{Hoplosauris morenoi Ramos-González \& Parra, sp. n.}

http://zoobank.org/BCE65057-D13A-4829-80BA-C9E73B9EB258

BIN: BOLD:AAH6701

Figures 3, 4, 11, 12, 18

Diagnosis. This species and $H$. heliconoides Butler share the following characters: valvae with sclerotized costa and apically rounded; in females, two-thirds (or more) of corpus bursae with longitudinal striation. However, in the case of $H$. moreno $i$ there are microspines on the sclerotized longitudinal striation only in the mid-ventral region (autapormorphy). The external morphology is highlighted by the grayish forewing, which is crossed by coppery-brown bands.

Description. Male (Fig. 3). Head: antennae filiform, subapically broadened; palpi porrect and subequal to eye diameter. Thorax: Patagia and tegulae covered by piliform ashy and brown scales. Tibial formula 0-2-4. Forewings: background color dark gray; termen rounded, with piliform dark-gray scales; basal band straight coppery-brown; antemedial band coppery-brown, slightly zigzagging; postmedial band coppery-brown, straight, twice as wide as the basal and antemedial bands; subterminal band whitish, zigzagging; apical spot slender and blackish which connects with subterminal band; terminal band formed by a dashed stripe of short coppery-brown spots; discal spot present and blackish. Hindwings: reduced, half the length of forewings, subrounded, pale ashy, with no visible modification at the base of anal margin; without discal spot. Wing venation in males (Fig. 18): forewing with two accessory 


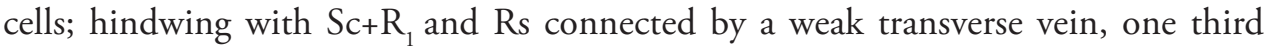
before the end of the cell; Rs and $M_{1}$ pedunculated; $M_{2}$ free and $M_{3}$ and $\mathrm{Cu}_{1}$ pedunculated; discal cell triangular and extends for a quarter of wing surface; anal cell present, formed by a weak transverse vein towards the middle of the discal cell that connects cubital stem with anal margin. Male genitalia (Fig. 11): valvae ensiform, costa sclerotized and rounded, cucullus apically extended, subapical setal tuft brush-like; saccus subrounded; juxta with subquadrangular base and indented posterior apex, with two disjointed lateral processes that have subtriangular apex, these processes extend to the height of the transtilla; uncus setose and curved; socius triangular; transtilla projected in a Y-shaped, with apices unequal in length. Aedeagus tubular; cornuti arranged as two longitudinal groups in the vesica. Female (Fig. 4). Similar to males but with filiform antennae slighter and hindwings not reduced, subquadrangular and pale ashy. Female genitalia (Fig. 12): ductus bursae one-sixth the length of corpus bursae; corpus bursae subpyriform, sclerotized, with straight longitudinal striations that exceed twothirds of corpus bursae and mid-ventral region with rows of microspines; posterior apophyses larger than anterior apophyses.

Type material. Holotype: 1 ${ }^{\lambda}$, pinned, ChiLE, Icalma, 02-II-2017, leg. H. Torres, "Holotype Hoplosauris morenoi" [red handwritten label] (MZUC-UCCC); allotype: 1 , pinned, Chile, Malalcahuello, 20-I-2017, leg. C. Zamora-Manzur, "Allotype Hoplosauris morenoi" [red handwritten label] (MZUC-UCCC).

Paratypes: 17 males, 7 females. CHILE: Diguillín: Volcán Chillán, 03-III-1979, coll. light traps (1 $\left.{ }^{\Uparrow}\right)$ (MZUC-UCCC); Las Trancas, 7-I-1987, leg. M. Beéche, "AMLP 0030" [wing slide] (1 Љ̂) (MZUC-UCCC); Las Trancas, 03/10-I-2011, leg. G. Moreno, "AMLP 0122" [female genitalia slide] (1 §̂, 3 ) (MZUC-UCCC); Las Trancas, 08-I-1996, leg. M. Beéche (1 ठ̊); Las Trancas, 16-I-1996, coll. Phototropic trap $(1$ 今) (MZUC-UCCC); Las Trancas, 14/20-I-2012, leg. G. Moreno, "UCCC_ MZUC_Lep_0388” [male ID code] (1 $\hat{\jmath}, 1$ †) (MZUC-UCCC). Malleco: Curacautín, 20-II-2008, leg. O. Vergara \& J. Guzmán, “BC LP 0039” [Barcode voucher] (1 ㅇ) (MZUC-UCCC); same as holotype but 21-II-2017, "AMLP 0300” [genitalia

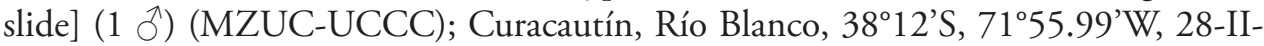
1995, leg. H. Thoeny [ID BC ZSM Lep 07781, barcode sequence 530 bp; ID BC ZSM Lep 07779, barcode sequence 570 bp; ID BC ZSM Lep 07628, barcode se-

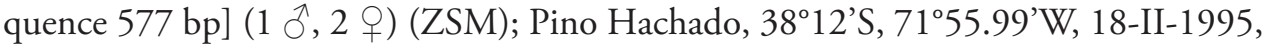
leg. H. Thoeny [ID BC ZSM Lep 07634, barcode sequence 582 bp] (1 Ô) (ZSM); Contulmo, Palo botado, 02-II-1953, leg. L.E. Peña (1 ठૈ) (MZUC-UCCC). Cautín: Termas de Río Blanco, III-1951, leg. L.E. Peña (2 Љ̋) (MZUC-UCCC). Coyhaique: Laguna Azul, 23-I-2008, leg. L.E. Parra, "Genitalia 0258" [genitalia in microvial] (1

đ) (MZUC-UCCC). Capitán Prat: Cochrane, Balsa Baker, 27-I-2008, "Genitalia 0245”, "Genitalia 0246”, "Genitalia 0257” [genitalia slides] leg. Muñoz-Escobar (4 ठ) (MZUC-UCCC).

Distribution. This species occurs between Diguillín and Capitán Prat provinces. It is distributed in parts of Santiago, Maule and Valdivian Forest biogeographic provinces, Central Chilean and Subantarctic subregions, Andean region.

Flight period. Specimens were captured from January to March. 

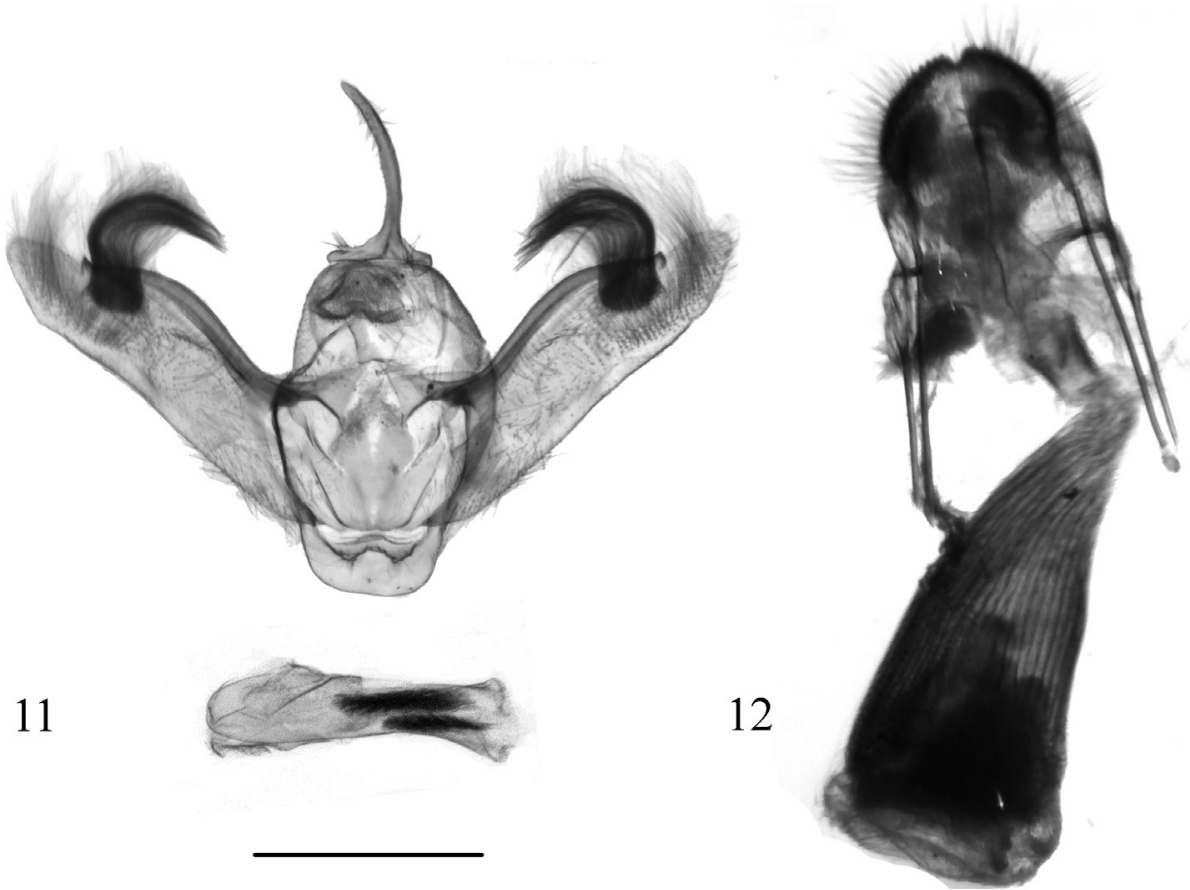

Figures I I, I 2. Genitalia of Hoplosauris morenoi Ramos-González \& Parra, sp. n. I I male genitalia (paratype, MZUC-UCCC, slide No. AMLP 0300) 12 female genitalia (paratype, MZUC-UCCC, slide No. AMLP 0122). Scale bar: $1 \mathrm{~mm}$.

Molecular data. BOLD:AAH6701. Five available sequences of DNA barcode: BC LP 0039 (Curacautín), BC ZSM Lep 07781 (Curacautín), BC ZSM Lep 07779 (Curacautín), BC ZSM Lep 07628 (Curacautín), BC ZSM Lep 07634 (Lonquimay). Maximum intraspecific distance: $1.15 \%$; Minimum genetic distance with $H$. pachrophylloides Parra: $7.74 \%$.

Etymology. The species name is dedicated to the naturalist and great collector $\mathrm{Sr}$ Guillermo Moreno Crisóstomo, Chillán, Chile.

\section{Butleriana phoenix Ramos-González \& Parra, sp. n.}

http://zoobank.org/AE5952C6-72B0-423A-B065-2F0DA3EBEB2C BIN: BOLD:AAD7597

Figures 5, 13, 19

Diagnosis. This species has a characteristic maculation pattern that easily distinguishes it from congeners: background color of forewings ashy-white, splashed with violaceous-red scales and crossed by dark violaceous-red antemedial and postmedial bands, which are more noticeable towards the costa. Butleriana phoenix differs from B. minor (Butler, 1882), B. oculata (Mabille, 1885), B. fumosa (Butler, 1882), and B. fasciata 
(Butler, 1882) by the presence of free Rs and M1 veins on the hindwings of males. Additionally, $B$. phoenix shares with $B$. fasciata by having the $A_{1}$ vein insinuated only at the base, but both species differ in male genitalia, as $B$. phoenix presents a strongly sclerotized costa, which exceeds the apex of cucullus, thereby forming a L-shaped notch at the apex of the valva.

Description. Male (Fig. 5). Head: antennae filiform, subapically broadened; palpi subequal to eye diameter, covered by erect piliform violaceous-red scales with third segment slightly curved down; frons covered with flattened reddish scales. Thorax: patagia covered by silvery-white and violaceous-red scales; tegulae covered by flattened scales, violaceous-red at proximal area and whitish towards its distal area. Tibial formula 0-24. Forewings: background color ashy-white, splashed with violaceous-red scales, with two irregular spots of golden-olive scales: one subapical the other in a post-basal position, on the anal margin; medial, cubital and anal veins framed by blackish scales, which are interspersed with the background color; termen rounded with piliform reddish scales; antemedial band dark violaceous-red, slightly arcuate; postmedial band dark violaceous-red, extended laterally towards the wing's apex at the height of the two accessory cells; subterminal band diffuse, formed by two slender violaceous-red stripes; presence of an oblique blackish apical spot, which connects with postmedial band; discal spot blackish. Hindwings: reduced, three-quarters the length of forewings, subrounded, ashy-white, with an extended, narrow and subtriangular lobe at the base of the anal margin; discal spot blackish. Wing venation (Fig. 19): forewing with two accessory cells; hindwing with $\mathrm{S}_{c+} \mathrm{R}_{1}$ and $\mathrm{Rs}$ anastomosed as far as one-third before the end of radial trunk; $\mathrm{Rs}, \mathrm{M}_{1}, \mathrm{M}_{2}, \mathrm{M}_{3}, \mathrm{Cu}_{1}$ and $\mathrm{Cu}_{2}$ are free and located on the vertices of discal cell; Rs closer to $M_{1}$ than to $S_{c}+R_{1} ; M_{2}$ closer to $M_{3} ; \mathrm{Cu}_{2}$ originating from the middle of cubital trunk; in anal lobe only with $A_{2}$ present, which is curved; $A_{1}$ only insinuated at base of lobe; discal cell polygonal and it is extended for half of wing surface. Male genitalia (Fig. 13): valvae subrectangular, with a bulbous projection in the central area of anterior edge, costa strongly sclerotized, exceeding the apex of cucullus, apical notch L-shaped; saccus subrounded; juxta with subquadrangular base and forked posterior apex also with two lateral processes having a setose subtriangular apex connected each other in the midventral region, at the height of transtilla; uncus glabrous and curved; transtilla simple. Aedeagus tubular; cornuti arranged as a longitudinal group in the vesica. Female unknown.

Type material. Holotype: 1 ふै, pinned, Chile, Chiloé, Quellón, 21-II-1951, leg. J.C. Vargas, "Museo", "AMLP 0141" [genitalia slide] "Holotype Butleriana phoenix" [red handwritten label] (MZUC-UCCC).

Paratypes: 4 males. Chile: Chiloé: Mocopulli, Ruta 5 Sur km 1170, 42²2.08'S, 7343.73’W, 182 m, 03-II-2017, leg. M. Ramos-G, M. Ramos-SM \& C. Rose (1 ふ) (MZUC-UCCC); Ancud, Pauldeo, 23-I-2005, “Colección Numhauser 2013", "AMLP 0100" [wing slide], leg. Numhauser (1 đ̋) (MZUC-UCCC). Palena: Fiordo Comau, San Ignacio del Huinay, pasture, 42²2.8'S, $72^{\circ} 24.78^{\prime} \mathrm{W}, 35 \mathrm{~m}, 04-\mathrm{I}-2008$, leg. A. Hausmann (1 đ) [ID BC ZSM Lep 11682, barcode sequence 658 bp] (ZSM); 


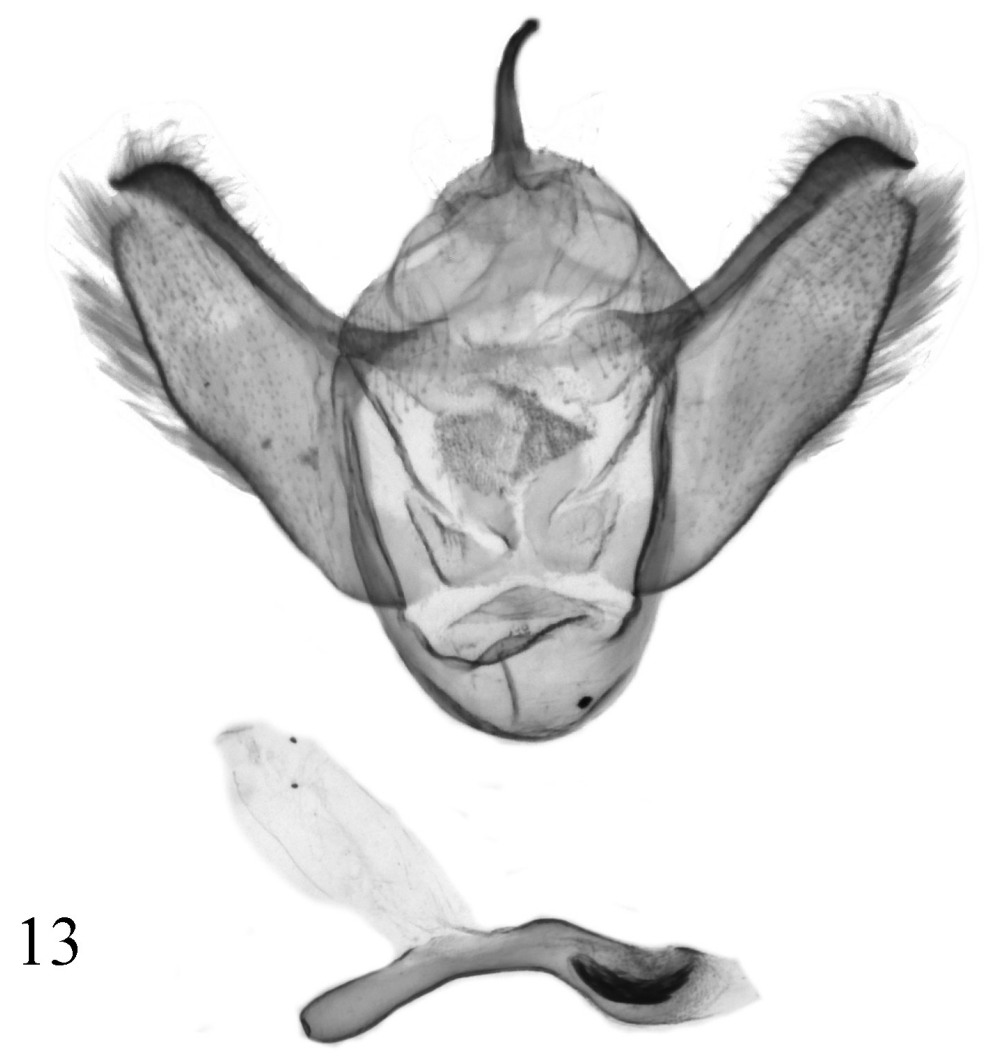

Figure 13. Male genitalia of Butleriana phoenix Ramos-González \& Parra, sp. n., male, holotype, MZUC-UCCC, slide No. AMLP 0141. Scale bar: $1 \mathrm{~mm}$.

Fiordo Comau, San Ignacio del Huinay, buildings, 42²2.86' S, 72²4.9'W, 20 m, 09I-2008, leg. A. Hausmann, T. Greifenstein \& L. Parra [ID BC ZSM Lep 11236, barcode sequence $632 \mathrm{bp}](1$ ठ $)$ (ZSM).

Distribution. This species occurs in Chiloé and Palena provinces. It is distributed in a part of the Valdivian Forest biogeographic province, Subantarctic subregion, Andean region.

Flight period. Specimens were captured from January to March.

Molecular data. BOLD:AAD7597. Two available sequences of DNA barcode: BC ZSM Lep 11682 (Huinay), BC ZSM Lep 11236 (Huinay). Maximum intraspecific distance: $0.79 \%$; Minimum genetic distance with B. minor: $10.59 \%$.

Etymology. The species name is a noun in the apposition, referring to the Phoenix (a mythical firebird), for the red/purple that is present in the moth's forewing coloration pattern. 


\section{Warrenaria onca Ramos-González \& Parra, sp. n.}

http://zoobank.org/D02F7D34-4754-437E-9BB5-7E49B2539D20

BIN not assigned

Figures 6, 14, 20

Diagnosis. This species can be easily distinguished from W. martha (Butler) by the presence of ashy-brown forewings, with less evident antemedial and postmedial bands, which have a ferruginous tone. Both species have an U-shaped posterior apex of the juxta in male genitalia but differs in the shape of the juxta's base: subquadrangular in Warrenaria onca but subtriangular in W. martha.

Description. Male (Fig. 6). Head: antennae filiform, subapically broadened; palpi twice as long as eye diameter, covered by piliform straight light-brown scales; frons covered with imbricated flattened ashy-brown scales. Thorax: patagia covered by juxtaposed flattened ashy-brown scales; tegulae covered by piliform whitish, blackish and ashybrown scales. Tibial formula 0-2-4. Forewings: background color ashy-brown splashed with blackish scales, slightly darker and with olivaceous tinge towards the costa and termen; $\mathrm{M}_{3}$ and $\mathrm{Cu}_{1}$ framed by blackish scales that cross the postmedial band; termen rounded, with dark piliform olivaceous-brown scales; basal region crossed by three wavy subcircular lines: proximal line light brown and diffuse, distal lines blackish and better defined than proximal one; costal margin of basal region only with a small subquadrate blackish spot, splashed with ferruginous-orange scales; antemedial band ferruginous-orange, slightly diffuse, zigzagging; postmedial band wavy, diffuse and composed of three slender ferruginous-orange stripes; costa of medial region mottled with blackish scales; subterminal band formed by two interrupted slender blackish stripes; adterminal band formed by rectangular interveinal spots; terminal band formed by blackish semicircles that are weakly connected with adterminal band; discal spot present and blackish. Hindwings: reduced, three-quarters the length of forewings, subrounded, dark brown, with an extended and subrounded lobe at the base of anal margin; discal spot blackish. Wing venation (Fig. 20): forewing with two accessory cells; hindwing with $\mathrm{Sc}_{\mathrm{c}} \mathrm{R}_{1}$ and Rs linked by a transverse vein a quarter before of the end of the cell; Rs, $M_{1}, M_{2}, M_{3}$ are free and located on the vertices of discal cell; $\mathrm{Cu}_{1}$ slightly arched, near the angle of cell; $\mathrm{Cu}_{2}$ inconspicuos, one-fifth before the angle of the cell; lobe crossed by sub-straight $\mathrm{A}_{1}$ and curved $\mathrm{A}_{2}$; discal cell polygonal and extend for half of wing surface. Male genitalia (Fig. 14): valvae subrectangular, costa strongly sclerotized, rounded apical notch with a small indention, about $1 / 16$ the length of valvae; saccus subquadrate; juxta with subquadrangular base and U-shaped posterior apex, with two lateral processes that have a setose triangular apex and are connected in the midventral region, at height of transtilla; uncus simple and slightly setose; transtilla simple. Aedeagus tubular; cornuti arranged as two longitudinal groups in the vesica. Female unknown.

Type material. Holotype: 1 ภ, pinned, CHILE, Nahuelbuta, Río Picoiquen, 22XII-1965, leg. Fetis, "AMLP 0137" [genitalia slide], "Holotype Warrenaria onca" [red handwritten label] (MZUC-UCCC). 


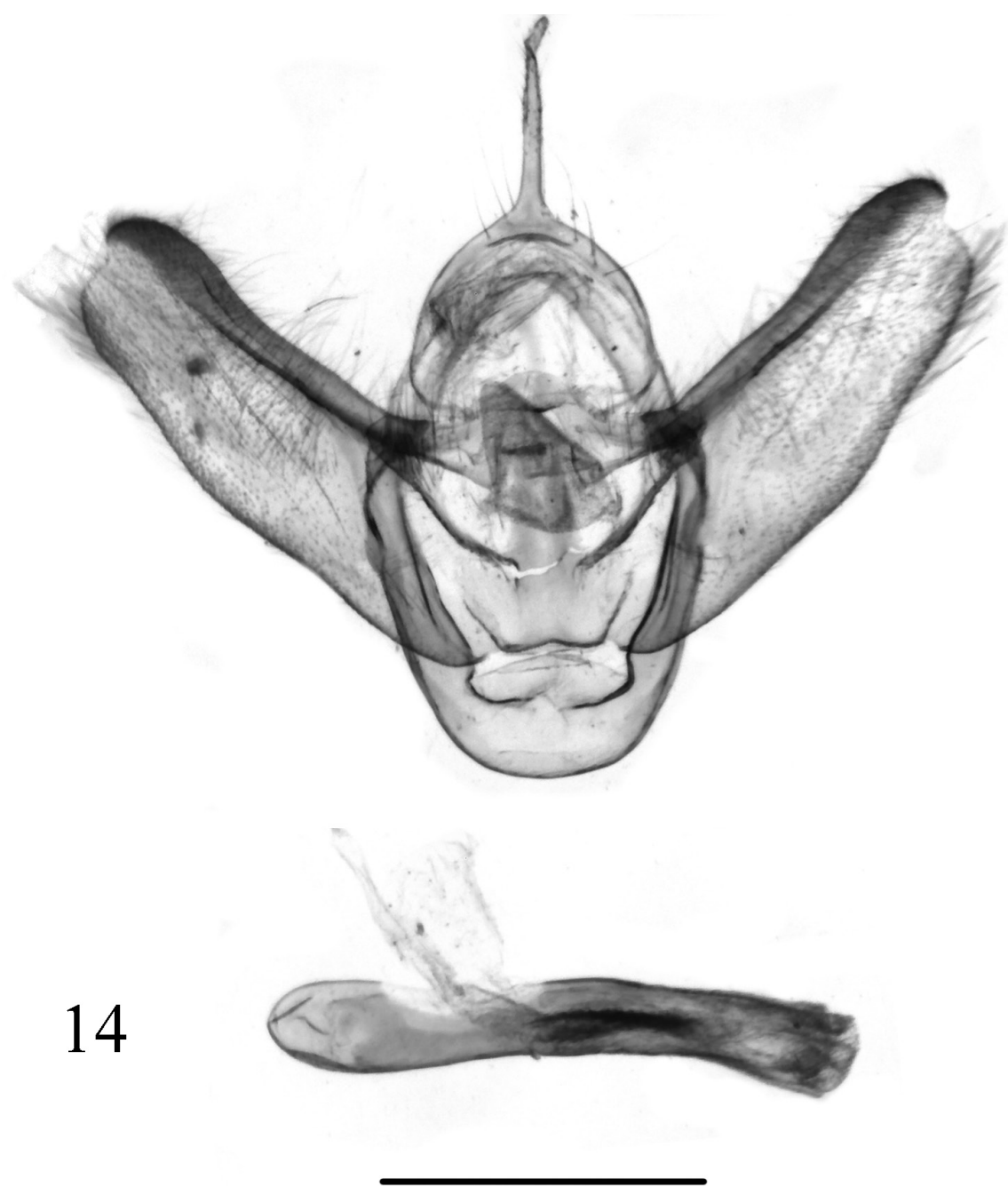

Figure 14. Male genitalia of Warrenaria onca Ramos-González \& Parra, sp. n., male, holotype, MZUCUCCC, slide No. AMLP 0137. Scale bar: $1 \mathrm{~mm}$.

Distribution. This species is only known from the type locality: Chile, Araucanía, Malleco, Angol, Nahuelbuta, Río Picoiquen. This locality belongs to Maule biogeographic province, Central Chilean subregion, Andean region.

Flight period. The single specimen was captured in December.

Etymology. The species name is a noun in apposition and is in reference to the jaguar (Panthera onca), a feline that inhabited the forests of southern South America until the end of the $19^{\text {th }}$ century and which gives its name to the type locality (Nahuelbuta) in Mapudungun language (nawel: jaguar; füta: big). 


\section{Fueguina araucana Ramos-González \& Parra, sp. n. http://zoobank.org/EA416114-32CA-4D92-BCEB-2F15171006F8 BIN not assigned}

Figures 7, 8, 15, 16, 21

Diagnosis. This species can be easily distinguished from F. varians (Butler) and F. celovalva Parra by its ashy forewings, crossed by dark-brown stripes, and a less-developed saccular process. Externally, it differs from $F$. magallanica Parra by its antemedial and postmedial bands, which are less angular in $F$ araucana. Can be distinguished from congeners by three other characters: the presence of disjointed subtriangular lateral processes in the juxta, the large subrounded apical indention, which extends approximately through half of valva, and having a globular corpus bursae which is short and subequal to the length of ductus bursae.

Description. Male (Fig. 7). Head: antennae filiform, subapically broadened; palpi porrect, slightly tilted up covered by straight piliform dark-brown scales and 1.5 times larger than eye diameter; frons and vertex covered with imbricated flattened whitish and dark-brown scales. Thorax: patagia covered by juxtaposed flattened whitish and dark-brown scales; tegulae covered by dark-brown scales splashed with black scales, piliform scales on the posterior region. Tibial formula 0-2-4. Forewings: background color ashy; medial and $\mathrm{Cu}_{1}$ veins framed by three elongated blackish spots, between postmedial and subterminal bands; termen rounded, with piliform light-brown scales; basal band blackish, curved, slightly zigzagging towards the inner margin; antemedial band dark brown, sinuous, which is thinner towards the costa and inner margin than in its medial sector; postmedial band sinuous and wide, formed by two brown-orange stripes mottled with dark brown and framed with blackish-brown scales; subterminal band dark brown, diffuse, cut off on its costal third by an ashy apical spot; discal spot present and blackish. Hindwings: same size as in females, subrectangular, ashybrown, with a digitiform lobe extended over the base of anal margin; discal spot not visible. Wing venation (Fig. 21): forewing with two accessory cells; hindwing with $\mathrm{Sc}_{\mathrm{c}} \mathrm{R}_{1}$ and $\mathrm{Rs}$ connected by a transverse vein towards one-third before the end of the cell; Rs and $M_{1}$ pedunculated; $M_{2}$ absent and $M_{3}$ near $\mathrm{Cu}_{1} ; \mathrm{Cu}_{1}$ is near the angle of the cell; $\mathrm{Cu}_{2}$ weak, one-fifth before the angle of the cell; lobe crossed by straight $\mathrm{A}_{1}$ and slightly curved $\mathrm{A}_{2}$; discal cell polygonal and extend for half of wing surface. Male genitalia (Fig. 15): valvae subrectangular, costa strongly sclerotized with rounded and setose apex, deep subrectangular apical notch, approximately half the length of valvae; cucullus projected in the apex of anterior edge, sacculus present and spine-like; saccus rounded; juxta with subquadrangular base and M-shaped posterior apex, with two disjointed lateral processes that have setose subtriangular apex and extends at the height of transtilla; uncus glabrous and straight. Aedeagus tubular; vesica armed with three cornutus. Female (Fig. 8): similar to males, but with filiform antennae slighter and subrectangular hindwings without lobe on the anal margin. Female genitalia (Fig. 16): ductus bursae striated and subequal in length to corpus bursae; corpus bursae 

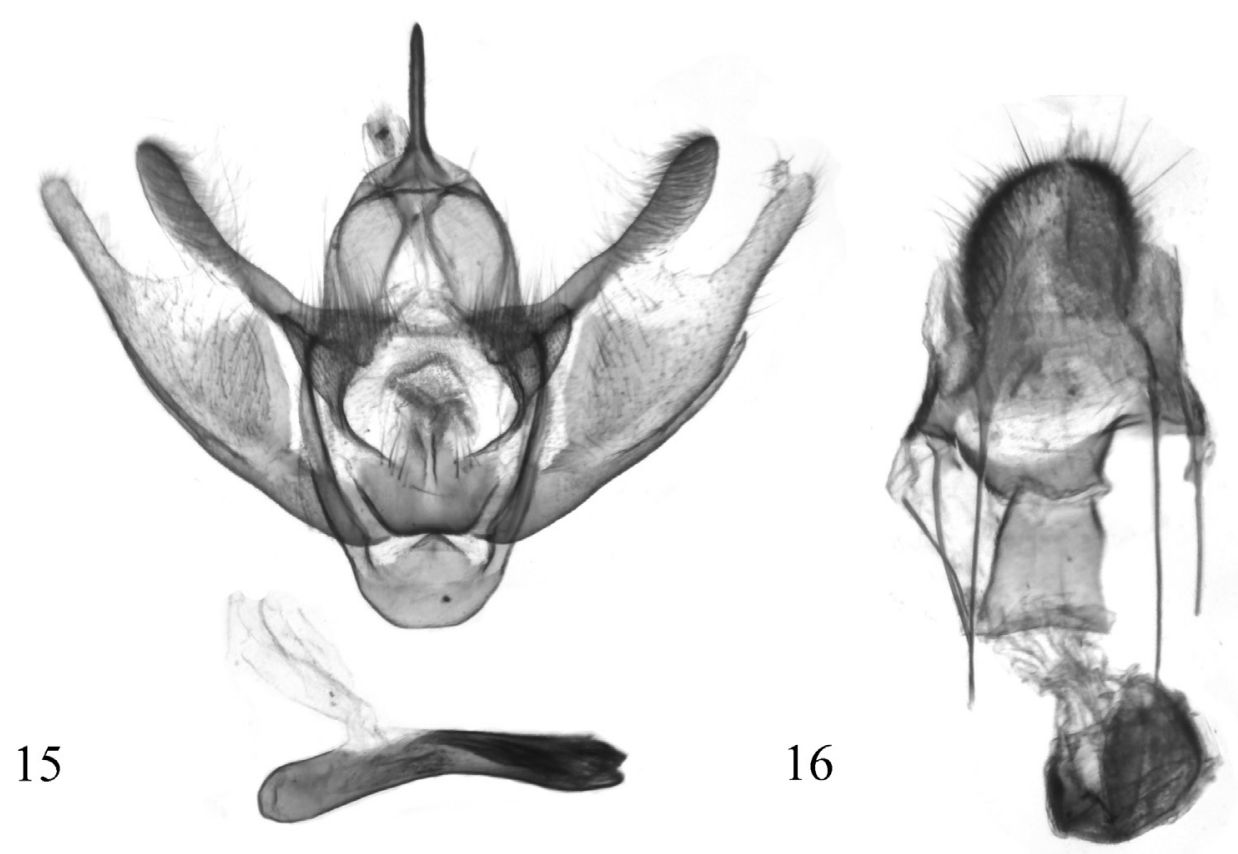

Figures 15, 16. Genitalia of Fueguina araucana Ramos-González \& Parra, sp. n. 15 male genitalia (holotype, MZUC-UCCC, slide No. AMLP 0139) 16 female genitalia (allotype, MZUC-UCCC, slide No. AMLP 0138). Scale bar: $1 \mathrm{~mm}$.

globular, membranous; cestum present, subrectangular and strongly sclerotized; posterior apophyses longer than anterior ones.

Type material. Holotype: 1 ô, pinned, Chile, Araucanía, Malleco, R.N. Malalcahuello-Nalcas, Corralco, 09-XII-2014, leg. L.E. Parra, "AMLP 0139” [genitalia slide], "UCCC_MZUC_Lep_0031" [ID code], "Holotype Fueguina araucana" [red handwritten label] (MZUC-UCCC); Allotype: 1 9, pinned, ChILE, Malleco, Río Blanco III-1951, leg. L.E. Peña, "Especie 23 H” [ID code, female], "AMLP 0138” [genitalia slide], "Allotype Fueguina araucana" [red handwritten label] (MZUC-UCCC).

Paratypes: 1 male, 3 females. Chile: Malleco: Curacautín, Termas de Río Blanco, 1050-1300 m, 21/24-II-1954, leg. L.E. Peña (1 ㅇ) (MZUC-UCCC). Cautín: Pucón, Termas de Río Blanco, II-1951, leg. L.E. Peña, "Especie 23 M" [ID code, male], "AMLP 0093” [wing slide] (1 Ô, 1 + ) (MZUC-UCCC); Pucón, Termas de Río Blanco, III-1951, leg. L.E. Peña (1 9 ) (MZUC-UCCC).

Distribution. This species occurs between Malleco and Cautín provinces. It is distributed in parts of Maule and Valdivian Forest biogeographic provinces, Subantarctic subregion, Andean region.

Flight period. Specimens were captured in December, February and March.

Etymology. The species name is dedicated to the Araucanía region, Chile, the locality where all specimens were collected. 

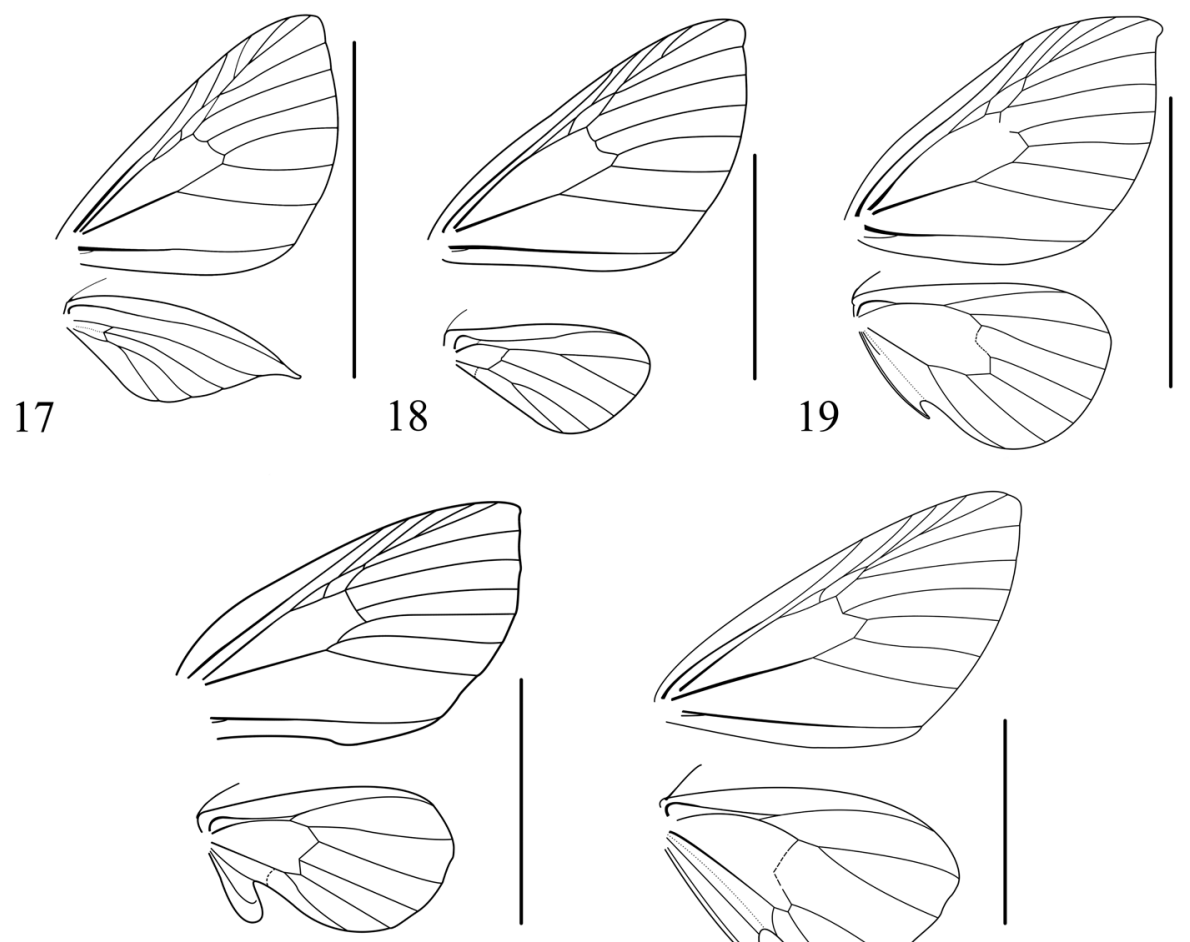

20

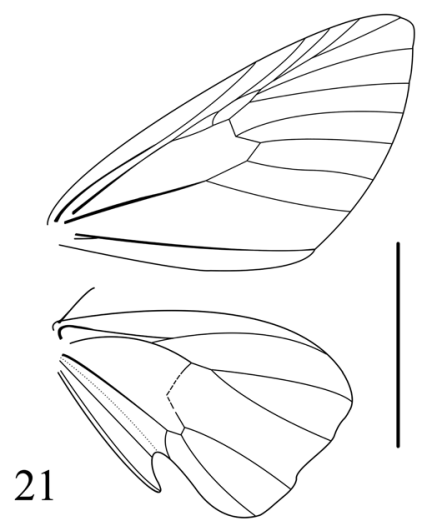

Figures 17-2I. Wing venation of males 17 Aloba carolinae Ramos-González \& Parra, sp. n. 18 Hoplosauris morenoi Ramos-González \& Parra, sp. n. 19 Butleriana phoenix Ramos-González \& Parra, sp. n. 20 Warrenaria onca Ramos-González \& Parra, sp. n. 2 I Fueguina araucana Ramos-González \& Parra, sp. n. Scale bar: $1 \mathrm{~cm}$

\section{Discussion}

The genus Hoplosauris was proposed by Butler (1882) and currently is the most species-rich Chilean trichopterygine genus with eight valid species (Parra et al. 2009, 2017). The species are: H. granitata (Fletcher, 1953), H. heliconoides Butler (1882), H. indistincta (Butler, 1882), H. macarenae Parra (2009), H. mabillei Parra (2009), H. pachrophylloides Parra (2009), H. schausi (Warren, 1908), and H. valeria Butler (1893). The genus can be recognized by three synapomorphies: a small flap, vesicle and/or tuft of piliform scales in the anal margin of the hindwing in males; a setal tuft in the subapical region of valvae; and microspines and striated areas in the internal surface if corpus bursae (Parra et al. 2009, 2017).

It is possible to include $H$. morenoi in this genus, due to the low genetic distance between this species and $H$. pachrophylloides (<8\%; Hausmann and Hebert 2009; Hausmann et al. 2011) and also because of the large number of characters shared with 
$H$. heliconoides, the type species. Some of these characters are the presence of short and porrect palpi; the connection of the $\mathrm{Sc}_{\mathrm{c}} \mathrm{R}_{1}$ and $\mathrm{Rs}$ veins by a weak transverse vein; and the pedunculated $\mathrm{M}_{3}$ and $\mathrm{Cu}_{1}$ veins; the absence of $\mathrm{Cu}_{2}$ and anal veins; the presence of an anal cell; the short and triangular discal cell in the forewings of males; the valvae with brush-like subapical setal tuft and apically projected cucullus; the ductus bursae which is one-sixth the length of corpus bursae; and the subpyriform completely sclerotized corpus bursae with longitudinal striation and rows of microspines. Thus, the number of species belonging to Hoplosauris increases to nine.

Several Chilean Trichopterygini (e.g., Butleriana, Warrenaria, Fueguina, Tomopteryx Philippi, Triptila Warren, Triptiloides Parra \& Santos-Salas, Pachrophylla Blanchard, and Parapachrophylla Parra) share ancestral characters in the male genitalia, e.g. valvae with indented posterior apex and juxta with a pair of lateral processes joined each other at transtilla height (Viidalepp 2011). This means that the venation pattern of the hindwings is particularly important for the determination of Chilean genera, especially in males (Parra 1991, 1996; Parra and Santos-Salas 1991, 1992).

Males of the genera Butleriana and Llampidken Parra have in common the shape of the lobes on the hindwing. However, venation of lobes is different in these genera, as well as some structures in the male genitalia (e.g., hooked socius, presence of saccular processes and costal arm in Llampidken). Butleriana is characterized by the presence of a single anal vein $\left(A_{2}\right)$ crossing the lobe (a synapomorphy that defines Butleriana). $A_{1}$, when present, is only a remnant vein, slightly visible at the base of the hindwing. This is different in Llampidken in which no anal veins go across the lobe (an autapomorphy) (Parra and Santos-Salas 1992; Parra et al. 2017). Although the genetic divergence between $B$. phoenix and the type species (B. minor) is high (approximately $11 \%$ ), it is possible to assign B. phoenix to the genus Butleriana because of the consistency in males of the hindwing and genital morphology, i.e., both species have similar valvae and a single anal vein through the subtriangular lobe, with the $A_{1}$ vein slightly visible at its base.

It is possible to distinguish Warrenaria by its reddish-brown coloration, rectangular valvae, and the shape of the uncus (Parra et al. 2017). Warrenaria onca is included in this genus because it shares with W. martha (type species) the maculation and wing venation general patterns. Other similarities are: the length of apical indention in the valvae, the shape of valva and socius, and the U-shaped juxta. All these characters, combined, are unique of Warrenaria and do not occur in other Chilean Trichopterygini.

Fueguina comprises three species: $F$. varians, F. celovalva, and $F$. magallanica. This genus can be distinguished by the presence of three features in males: a lobe at the hindwing base with two anal veins, a spiniform saccular process, and a deep indention on the cucullus region (Parra 1991; Parra et al. 2017). It is possible to include F. araucana in this taxon because of the shape and venation of hindwing lobe, the presence of a costal process, and the presence of a spiniform saccular process with a deep apical indention. Fueguina araucana and F. magallanica share the following characters: general wing venation pattern, general shape of valvae and juxta, and the similar maculation pattern. However, there are distinctive characters in $F$. araucana: distinctive lateral processes of juxta; a deeper apical indention of valvae (in this sense, similar to $F$. varians 
and F. celovalva but more rounded, as in F. magallanica); and the shape of bursa copulatrix. The large number of common characters between $F$. magallanica and $F$. araucana suggests that both species are closely related, placing them as the sister-species.

Regarding Aloba, Warren (1895) was the first to placed this genus in the tribe Trichopterygini and included only one species. Nevertheless, this species was not considered to belong to the Trichopterygini in later works (e.g., Parra et al. 2017). After analyzing the anatomical features of this species, it is possible to recognize it as a member of the Trichopterygini and re-assign it to the tribe. This species shares with the Trichopterygini the diagnostic characters that defines the tribe, such as the reduction in the anal margin of male hindwings with subsequent simplification of venation and the presence of a sternal pouch in the tympanic opening (Dugdale 1980; Parra et al. 2017). Aloba can be considered as the taxon morphologically closest to Hoplosauris, based on the absence of lobe and anal veins in the hindwings of males, the presence of a cucullus projected apically, and a setal tuft. This taxonomic relationship is supported by molecular phylogenetic analyses (Ramos-González et al. unpublished data; Brehm et al. submitted).

Finally, considering all these new findings, the number of Chilean Trichopterygini increases to 15 genera and 45 species.

\section{Acknowledgements}

We thank James Austrums for improving the manuscript linguistically and Elier Fonseca for his constructive criticism of the manuscript. We also thank Axel Hausmann for sharing his barcoding data of Chilean geometrid moths deposited in ZSM. M.R.-G. thanks to Manuel Astrosa, Alcides Williams, Carolina Rose, and Mario Ramos San Martín who collaborated in the field collection of specimens in Los Queñes, Concepción and Chiloé. C.Z.-M. and D.S. appreciate the financial support from project EDPG LPR-161 of Dirección de Postgrado, Universidad de Concepción and from "Beca Doctorado Nacional" CONICYT No. 21161423 and CONICYT No. 21180592 respectively. This research was supported by Vicerrectoría de Investigación y Desarrollo of the Universidad de Concepción (VRID 214.113.087-1.0).

\section{References}

Bartlett-Calvert W (1893) Nuevos lepidópteros de Chile. Anales de la Universidad de Chile 84: 813-834. https://anales.uchile.cl/index.php/ANUC/article/view/20691/21857

Brehm G (2015) Three new species of Hagnagora Druce, 1885 (Lepidoptera, Geometridae, Larentiinae) from Ecuador and Costa Rica and a concise revision of the genus. Zookeys 537: 131-156. https://doi.org/10.3897/zookeys.537.6090

Brehm G (2018) Revision of the genus Callipia Guenée, 1858 (Lepidoptera, Geometridae), with the description of 15 new taxa. European Journal of Taxonomy 404: 1-54. https://doi.org/10.5852/ejt.2018.404 
Butler AG (1882) Heterocerous Lepidoptera collected in Chili by Thomas Edmonds, Esq. Part III-Geometrites. Transactions of the Entomological Society of London 30(3): 339-427. https://doi.org/10.1111/j.1365-2311.1882.tb01580.x

Butler AG (1893) On a small collection of Lepidoptera from Chili. The Annals and Magazine of Natural History, including Zoology Botany, and Geology 12(6): 457-467. https://doi. org/10.1080/00222939308677653

Dugdale JS (1980) Australian Trichopterygini (Lepidoptera: Geometridae) with descriptions of eight new taxa. Australian Journal of Zoology 28: 301-340. https://doi.org/10.1071/ ZO9800301

Fletcher DS (1953) Some new species of Geometridae from Argentina and Chile. Acta Zoológica Lilloana 12: 367-380.

Gaston KJ, Scoble MJ, Cook A (1995) Patterns in species descriptions: a case study using the Geometridae (Lepidoptera). Biological Journal Linnean Society 55(3): 225-237. https://doi.org/10.1111/j.1095-8312.1995.tb01061.x

Hausmann A, Haszprunar G, Hebert P (2011) DNA barcoding the geometrid fauna of Bavaria (Lepidoptera): successes, surprises, and questions. PLoS ONE 6(2): e17134. https://doi. org/10.1371/journal.pone.0017134

Hausmann A, Hebert P (2009) Order Lepidoptera, family Geometridae (part 2): the Geometridae of the UAE revised in the light of mtDNA data. In: Van Harten T (Ed.) Arthropod Fauna of the UAE 2. Dar Al Ummah Printing, Publishing, Distribution \& Advertising, Adu Dhabi, United Arab Emirates, 468-479.

Hausmann A, Parra LE (2009) An unexpected hotspot of moth biodiversity in Chilean northern Patagonia (Lepidoptera, Geometridae). Zootaxa 1989: 23-38.

Holloway JD (1997) The moths of Borneo: family Geometridae, subfamilies Sterrhinae and Larentiinae. Malayan Nature Journal 51: 1-242.

Klots AB (1970) Lepidoptera. In: Tuxen SL (Ed.) Taxonomist's Glossary of Genitalia in Insects. Second Enlarged Edition. Ejnar Munksgaard, Copenhagen, 115-130.

Morrone JJ (2015) Biogeographical regionalisation of the Andean region. Zootaxa 3936(2): 207-236. https://doi.org/10.11646/zootaxa.3936.2.3

Ounap E, Viidalepp J, Truuverk A (2016) Phylogeny of the subfamily Larentiinae (Lepidoptera: Geometridae): integrating molecular data and traditional classifications. Systematic Entomology 41(4): 824-843. https://doi.org/10.1111/syen.12195

Parra LE (1991) Revisión y filogenia del género Pachrophylla Blanchard, 1852 (sensu auctorum) (Geometridae: Larentiinae: Trichopterygini). Gayana Zoología55(2): 145-199.

Parra LE (1995) Lepidoptera. In: Simonetti JA, Arroyo MTK, Spotorno AE, Lozada E (Eds) Diversidad Biológica de Chile. CONICYT, Santiago, Chile, 269-279.

Parra LE (1996) Trichopterygini Neotropicales IV: descripción de nuevos géneros y especies de Chile (Lepidoptera: Geometridae). SHILAP Revista de Lepidopterología 24(93): 37-54.

Parra LE, Jiménez-Urrutia MC, Zamora-Manzur C (2009) Revision of the genus Hoplosauris Butler, 1882 (Lepidoptera: Geometridae). Zootaxa 1989: 39-54.

Parra LE, Santos-Salas CP (1991) Trichopterygini Neotropicales II (Lepidoptera: Geometridae): El complejo Rhopalodes Guenée, 1857. Gayana Zoología 55: 267-303. 
Parra LE, Santos-Salas CP (1992) Trichopterygini Neotropicales III: género y especie nuevos para Chile (Lepidoptera: Geometridae). Boletín de la Sociedad de Biología de Concepción 63: 151-156.

Parra LE, Vargas HA, Sanzana MJ, Hernández CE (2017) Phylogenetic study of the genera of Trichopterygini from austral South America (Lepidoptera: Geometridae): a new classification. Gayana 81(2): 64-99. https://doi.org/10.4067/S0717-65382017000200064

Parra LE, Villagrán-Mella R (2008) Orden Lepidoptera (mariposas). In: CONAMA (Ed.) Biodiversidad de Chile, Patrimonio y Desafíos, $2^{\circ}$ Edición. Ocho Libros Editores, Santiago, Chile, 159-165.

Ratnasingham S, Hebert P (2007) BOLD: The Barcode of Life Data System (www.barcodinglife.org). Molecular Ecology Notes 7(3): 355-364. https://doi.org/10.1111/j.14718286.2007.01678.x

Ratnasingham S, Hebert P (2013) A DNA-based registry for all animal species: The Barcode Index Number (BIN) system. PLoS ONE 8(7): e66213. https://doi.org/10.1371/journal. pone.0066213

Rindge FH (1987) The Euphitecia (Lepidoptera: Geometridae) of Chile. Bulletin of the American Museum of Natural History 186(3): 269-363. http://hdl.handle.net/2246/912

Rindge FH (1991) The Eupithecia (Lepidoptera: Geometridae) of Chile II. American Museum Novitates 3020: 1-14. http://hdl.handle.net/2246/5049

Scoble MJ (1995) The Lepidoptera: Form, Function and Diversity. Oxford University Press, Oxford, $404 \mathrm{pp}$.

Scoble MJ (1999) Geometrid Moths of the world: a Catalogue. Vols 1 and 2. CSIRO Publishing, Collingwood, 1016 pp. https://doi.org/10.1071/9780643101050

Scoble MJ, Gaston KJ, Crook A (1995) Using taxonomic data to estimate species richness in Geometridae. Journal of the Lepidopterists' Society 49: 136-147.

Scoble MJ, Hausmann A (2007) Online list of valid and available names of the Geometridae of the World. Lepidoptera Barcode of Life, iBOL. http://www.lepbarcoding.org [Accessed on 2018-9-19]

Sihvonen P, Mutanen M, Kaila L, Brehm G, Hausmann A, Staude HS (2011) Comprehensive molecular sampling yields a robust phylogeny for geometrid moths (Lepidoptera: Geometridae). PLoS ONE 6(6): e20356. https://doi.org/10.1371/journal.pone.0020356 https:// doi.org/10.1371/journal.pone.0020356

Van Nieukerken EJ, Kaila L, Kitching IJ, Kristensen NP, Lees DC, Minet J, Mitter C, Mutanen M, Regier JC, Simonsen TJ, Wahlberg N, Yen SH, Zahiri R, Adamski D, Baixeras J, Bartsch D, Bengtsson BA, Brown JW, Bucheli SR, Davis DR, Prins JD, Prins WD, Epsteia ME, Gentili-Poole P, Gielis C, Hättenschwiler P, Hausmann A, Holloway JD, Kallies A, Karsholt O, Kawahara AY, Koster S, Kozlov MV, Lafontaine D, Lamas G, Landry JF, Lee S, Nuss M, Park KT, Penz C, Rota J, Schintlmeister A, Schmidt BC, Sohn JC, Solis MA, Tarmann GM, Warren AD, Weller S, Yakovlev RV, Zolotuhin VV, Zwick A (2011) Order Lepidoptera Linnaeus. In: Zhang Z-Q (Ed.) Animal biodiversity: an outline of higher-level classification and survey of taxonomic richness. Zootaxa 3148: 212-221.

Viidalepp J (2011) A Morphological review of tribes in Larentiinae (Lepidoptera: Geometridae). Zootaxa 3136: 1-44. 
Vojnits AM (1985) New South American genera and species of Eupithicini (Lepidoptera: Geometridae). Acta Zoologica Hungarica 31: 405-418.

Vojnits AM (1992) New data to the Eupithecia fauna of Chile and Peru (Lepidoptera: Geometridae). Acta Zoologica Hungarica 38(1-2): 125-144.

Vojnits AM (1994) New data on the Eupithecia fauna of Chile (Lepidoptera, Geometridae). Entomofauna 15(32): 361-376.

Warren W (1895) New species and genera of Geometridae in the Tring Museum. Novitates Zoologicae 2: 82-159. https://biodiversitylibrary.org/page/3859357

Warren W (1908) Descriptions of new species of South American geometrid moths. Proceedings of the United States National Museum 34: 91-110. https://doi.org/10.5479/ si.00963801.1601.91

Zamora-Manzur C, Parra LE, Jaque E (2011) Patrones de distribución de los geométridos de la Región del Biobío, Chile: una aproximación para su conservación. Revista Chilena de Historia Natural 84: 465-480. https://doi.org/10.4067/S0716-078X2011000400001 